INVITED REVIEW

\title{
Sodium/iodide symporter: a key transport system in thyroid cancer cell metabolism
}

\author{
Sebastiano Filetti, Jean-Michel Bidart ${ }^{2}$, Franco Arturi, Bernard Caillou ${ }^{3}$, Diego Russo ${ }^{1}$ \\ and Martin Schlumberger ${ }^{4}$ \\ Dipartimento di Medicina Sperimentale e Clinica, ${ }^{1}$ Cattedra di Farmacologia, Facoltà di Farmacia, Università di Catanzaro, 88100 Catanzaro, Italy, \\ Departments of ${ }^{2}$ Clinical Biology, ${ }^{3}$ Pathology and ${ }^{4}$ Nuclear Medicine, Institut Gustave-Roussy, 94805 Villejuif, France \\ (Correspondence should be addressed to S Filetti, Dipartimento di Medicina Sperimentale e Clinica, Università degli Studi di Catanzaro, Via T. \\ Campanella, 115-88100 Catanzaro, Italy; Email: filetti@tin.it)
}

\begin{abstract}
The recent cloning of the gene encoding the sodium/iodide symporter (NIS) has enabled better characterization of the molecular mechanisms underlying iodide transport, thus opening the way to clarifying its role in thyroid diseases. Several studies, at both the mRNA and the protein expression levels, have demonstrated that TSH, the primary regulator of iodide uptake, upregulates NIS gene expression and NIS protein abundance, both in vitro and in vivo. However, other factors, including iodide, retinoic acid, transforming growth factor- $\beta$, interleukin- $1 \alpha$ and tumour necrosis factor $\alpha$, may participate in the regulation of NIS expression. Investigation of NIS mRNA expression in different thyroid tissues has revealed increased levels of expression in Graves' disease and toxic adenomas, whereas a reduction or loss of NIS transcript was detected in differentiated thyroid carcinomas, despite the expression of other specific thyroid markers. NIS mRNA was also detected in non-thyroid tissues able to concentrate radioiodine, including salivary glands, stomach, thymus and breast.

The production of specific antibodies against the NIS has facilitated study of the expression of the symporter protein. Despite of the presence of high levels of human (h)NIS mRNA, normal thyroid glands exhibit a heterogeneous expression of NIS protein, limited to the basolateral membrane of the thyrocytes. By immunohistochemistry, staining of hNIS protein was stronger in Graves' and toxic adenomas and reduced in thyroid carcinomas.

Measurement of iodide uptake by thyroid cancer cells is the cornerstone of the follow-up and treatment of patients with thyroid cancer. However, radioiodide uptake is found only in about $67 \%$ of patients with persistent or recurrent disease. Several studies have demonstrated a decrease in or a loss of NIS expression in primary human thyroid carcinomas, and immunohistochemical studies have confirmed this considerably decreased expression of the NIS protein in thyroid cancer tissues, suggesting that the low expression of NIS may represent an early abnormality in the pathway of thyroid cell transformation, rather than being a consequence of cancer progression.

The relationship between radioiodine uptake and NIS expression by thyroid cancer cells require further study. New strategies, based on manipulation of NIS expression, to obtain NIS gene reactivation or for use as NIS gene therapy in the treatment of radiosensitive cancer, are also being investigated.
\end{abstract}

European Journal of Endocrinology 141 443-457

\section{Role of iodine in thyroid physiology and pathophysiology}

\section{Iodine in thyroid physiology}

Iodine represents an essential element in thyroid physiology, being a critical component of thyroxine and tri-iodothyronine molecules, and a key regulator of thyroid gland function. Thus dietary iodide supply influences the functional activity of the thyroid gland, iodine deficiency being the main cause of endemic goiter. Furthermore, iodine directly modulates thyroid sensitivity to thyroid-stimulating hormone (TSH), and intrathyroidal iodine has a generally inhibitory effect on thyroid function, independently of the TSH concentration. This autoregulatory effect of iodine encompasses many aspects of thyroid function, including iodide transport mechanism, iodide organification, thyroid hormone synthesis and secretion, and thyroid intermediary metabolism.

The first step of iodine thyroid metabolism is represented by the thyroid trapping and concentration of iodide from the blood, which are achieved by an active, energydependent transport process across the basolateral plasma membrane of the thyrocytes (Fig. 1). The recent cloning $(1,2)$ of the gene encoding the protein responsible 
for this process, the sodium/iodide symporter (NIS), enabled better characterization of the molecular mechanisms underlying the iodide transport, thus opening the way to clarify its role in thyroid diseases (Table 1).

Radioactive isotopes of iodine have been used first as tracers of thyroid function and, subsequently, for treatment of hyperthyroidism and benign thyroid diseases. The evidence that iodine transport is present in thyroid neoplastic tissues has been the basis for the use of radioiodine in the diagnosis and treatment of patients with thyroid cancer.

In this review, we will discuss the more recent knowledge concerning the NIS system and its regulation in neoplastic thyroid cells, attempting to correlate the molecular mechanisms underlying the defective iodide transport in cancer cells with the clinical management of thyroid cancer patients. Prospectively, the availability of an efficient iodide transport system is a prerequisite

\section{Colloid}

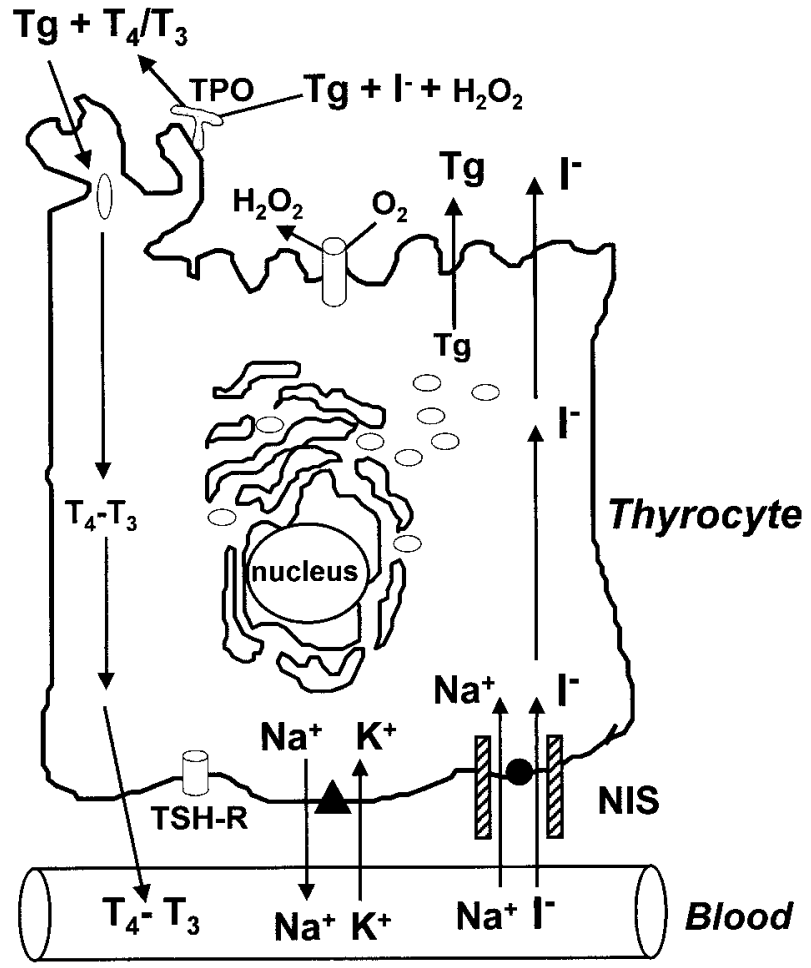

Figure 1 Schematic representation of the iodide uptake and biosynthetic pathway of thyroid hormones in thyrocytes. $\mathrm{I}^{-}$is actively accumulated across the basolateral plasma membrane of the thyrocyte in a process catalyzed by the NIS. This transport is driven by the $\mathrm{Na}^{+}$gradient generated under ATP hydrolysis by $\mathrm{Na}^{+} / \mathrm{K}^{+}$-ATPase. The iodide is passively translocated across the apical membrane of the thyrocyte into the colloid, where it is used to iodinate the thyroglobulin $(\mathrm{Tg})$. This reaction, called ' $\mathrm{I}$ organification', is catalyzed by TPO and requires $\mathrm{H}_{2} \mathrm{O}_{2}$. The iodinated $\mathrm{Tg}$, containing thyroid hormones, is stored in the colloid. Thyroid hormones, thyroxine $\left(T_{4}\right)$ and tri-iodothyronine $\left(T_{3}\right)$ are released from $\mathrm{Tg}$ and secreted in the blood. All steps in the thyroid hormone biosynthetic pathway are stimulated by $\mathrm{TSH}$. to obtaining optimal benefit from radioiodine treatment of thyroid diseases, including primary and metastatic papillary and follicular carcinomas and, by the use of NIS gene therapy, to extending this 'targeted radiotherapy' to radiosensitive non-thyroid carcinomas.

\section{NIS as carrier of iodide transport in thyroid cells}

Iodide concentration occurs in the thyroid gland by 20 to 40 -fold with respect to the anion concentration in plasma. Then, iodide $\left(\mathrm{I}^{-}\right)$is transported transcellularly from the basolateral to the apical membrane of the thyrocyte, where it is organified. NIS-catalyzed active accumulation of $\mathrm{I}^{-}$from the interstitium into the cell is achieved against an electrochemical gradient, whereas apical $\mathrm{I}^{-}$efflux (translocation of $\mathrm{I}^{-}$to the follicular lumen) is passively achieved through a putative $\mathrm{I}^{-}$channel. NIS couples the energy released by the inward 'downhill' translocation of $\mathrm{Na}^{+}$down its electrochemical gradient, generated by $\mathrm{Na}^{+} / \mathrm{K}^{+}$ATPase, to driving the simultaneous inward 'uphill' translocation of $\mathrm{I}^{-}$against its electrochemical gradient (3). This process is competitively inhibited by thiocyanate, perchlorate and other anions (4). Differently from other tissues able to concentrate iodide, the thyroid gland alone is able to achieve prolonged $\mathrm{I}^{-}$accumulation, as a result of the prompt organification of $\mathrm{I}^{-}$in the tyrosyl residues of thyroglobulin, through a reaction catalyzed by thyroid peroxidase (TPO).

\section{Iodide concentration and utilization by thyroid cells, and its regulation}

Many studies, using different experimental models, have elucidated the role of TSH and the activation of the cAMP pathway as the principal regulator of iodide uptake. Many other factors, including insulin, insulinlike growth factor (IGF)-I, epidermal growth factor and iodide itself also influence iodide uptake in the thyroid gland (3). The molecular characterization of the regulation of iodide transport has become possible since the cloning of the NIS gene. Indeed, in recent years, the regulation of NIS expression has been extensively studied, at both mRNA and protein levels, by using either in vivo or in vitro experimental models (Table 2) (5-14). In primary cultured human thyrocytes, TSH and forskolin upregulate NIS gene expression and NIS protein abundance, with 2.5- to 2.7-fold and 2.4 - to 2.7 -fold increases after $24 \mathrm{~h}$ and $48 \mathrm{~h}$ respectively (15). These findings are concordant with results obtained in FRTL-5 and PC Cl3 rat thyroid cells $(9,10)$. Re-addition of TSH to TSH-negative FRTL-5 cells significantly increased NIS mRNA (approximately sixfold maximal stimulation after $24 \mathrm{~h}$ ), followed by a slower increase in NIS protein synthesis (9). Forskolin and dibutyryl-cAMP mimicked the stimulatory effect of TSH on both the $\mathrm{I}^{-}$transport activity and mRNA levels. 
Table 1 Characteristics of iodide transport and human NIS gene and NIS protein.

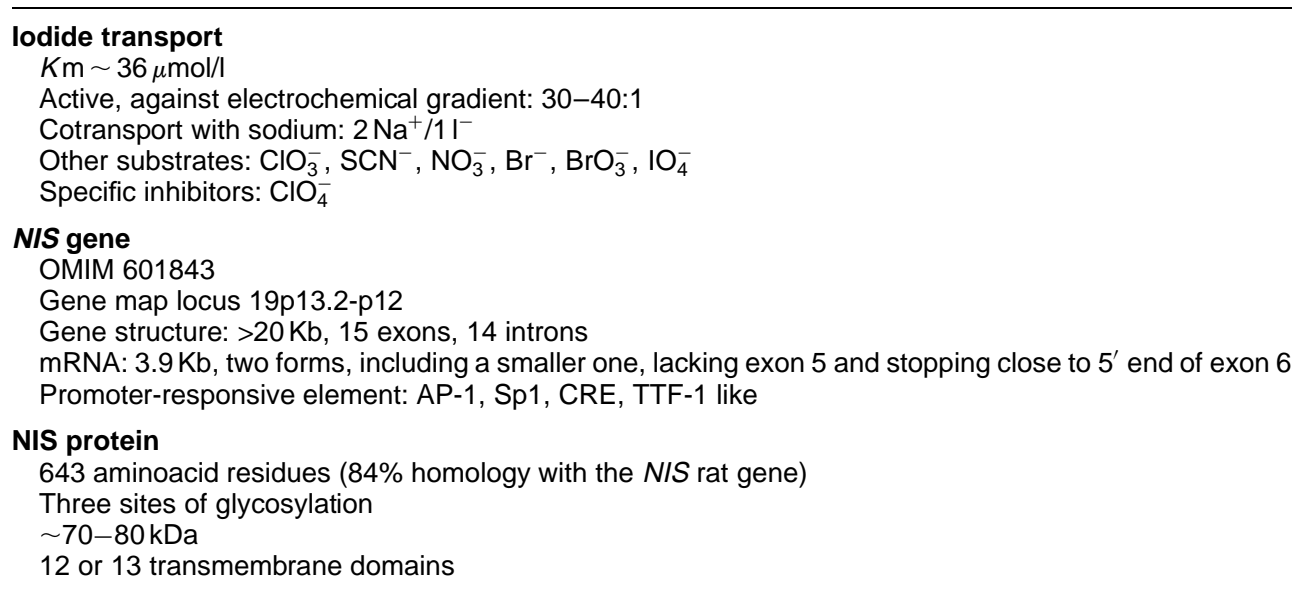

OMIM, Online Mendelian inheritance in man; AP-1, activating protein-1; Sp1, stimulating protein-1; CRE, cAMP response element; TTF-1, thyroid-specific transcription factor-1.

However, iodide uptake was enhanced 27-fold, with an increase evident after a 24-h stimulation, whereas the concentration of NIS protein increased only after $36 \mathrm{~h}$, by $\sim 2.6$-fold. Taken together, these observations suggest that other mechanisms, including cAMP-dependent phosphorylation and coregulation by other activating or inhibiting proteins, may participate in the posttranslational regulation of NIS activity, as proposed previously (16).

NIS upregulation by TSH has also been described in vivo (5). In hypophysectomized rats with markedly low TSH concentrations, NIS protein expression is low, but increases promptly after a single injection of TSH. Accordingly, in rats maintained on an $\mathrm{I}^{-}$-deficient diet or treated with propylthiouracil, increased TSH circulating concentrations paralleled increased NIS protein expression. Also, in dog thyroid glands (6), the expression of NIS mRNA is upregulated by goitrogenic treatment. Furthermore, administration of iodide, even in low doses, inhibited the expression of TPO and NIS (Table 2) mRNAs without affecting either the TSH concentrations or the expression of thyroglobulin or TSH receptor

Table 2 Regulation of NIS mRNA and protein expression.

\begin{tabular}{|c|c|c|c|c|}
\hline \multirow[b]{2}{*}{ Agent } & \multirow[b]{2}{*}{ Experimental model } & \multicolumn{2}{|c|}{ Effect on NIS } & \multirow[b]{2}{*}{ Reference } \\
\hline & & mRNA & Protein & \\
\hline TSH & $\begin{array}{l}\text { In vivo, rats } \\
\text { In vivo, dogs } \\
\text { Human thyrocytes } \\
\text { FRTL-5 cells } \\
\text { PC Cl } 3 \text { cells }\end{array}$ & $\begin{array}{l}+ \\
+ \\
+ \\
+\end{array}$ & $\begin{array}{l}+ \\
+ \\
+\end{array}$ & $\begin{array}{l}5 \\
6 \\
7,8 \\
9 \\
10\end{array}$ \\
\hline Forskolin/db-cAMP & $\begin{array}{l}\text { Human thyrocytes } \\
\text { FRTL- } 5 \text { cells } \\
\text { PC C } 13 \text { cells }\end{array}$ & $\begin{array}{l}+ \\
+ \\
+\end{array}$ & $\begin{array}{l}+ \\
+\end{array}$ & $\begin{array}{l}7,8 \\
9 \\
10\end{array}$ \\
\hline lodide & $\begin{array}{l}\text { In vivo, rats } \\
\text { In vivo, dogs }\end{array}$ & - & - & $\begin{array}{l}5 \\
6\end{array}$ \\
\hline Retinoic acid & $\begin{array}{l}\text { FRTL- } 5 \text { cells } \\
\text { Human thyroid } \\
\text { carcinoma cells }\end{array}$ & $\begin{array}{l}- \\
+\end{array}$ & & $\begin{array}{l}11 \\
11\end{array}$ \\
\hline TGF- $\beta$ & FRTL-5 cells & $-{ }^{*}$ & & 12 \\
\hline IL-1/IFN $\gamma / \mathrm{TNF} \alpha$ & $\begin{array}{l}\text { FRTL- } 5 \text { cells } \\
\text { Human thyrocytes }\end{array}$ & $\begin{array}{l}-^{*} \\
-^{*}\end{array}$ & & $\begin{array}{r}13 \\
7\end{array}$ \\
\hline Oncostatin M & FRTL-5 & $-^{*}$ & & 14 \\
\hline
\end{tabular}

db-cAMP, dibutyryl-cAMP; TGF- $\beta$, transforming growth factor $\beta$; IL-1, interleukin-1; IFN $\gamma$, interferon- $\gamma$;

$\mathrm{TNF} \alpha$, tumor necrosis factor $\alpha$.

$-{ }^{*}$, inhibition of TSH stimulation. 
(TSH-R) mRNAs. This suggests that an increase in iodide, probably through its intracellular concentration, may downregulate expression of the NIS gene.

Factors other than TSH and iodide may participate in the regulation of NIS expression. Retinoic acid was found to upregulate iodide transport in human follicular thyroid carcinoma cell lines, whereas a downregulation was observed in non-transfected FRTL-5 cells (11). In the same cells, transforming growth factor- $\beta$ inhibited TSH stimulation of NIS mRNA and protein expression (12). In both FRTL-5 and primary thyroid follicular cell cultures, interleukin- $1 \alpha$, tumour necrosis factor $\alpha$ and interferon- $\gamma$ inhibited TSHinduced NIS gene expression and iodide uptake $(7,13)$ (Table 2).

\section{NIS tissue-expression studies}

\section{NIS gene promoter characterization and NIS gene expression}

To investigate the transcriptional level of NIS mRNA regulation, the $5^{\prime}$-flanking region of the NIS gene has been characterized. The tentative human NIS gene transcriptional start site has been located 375 nucleotides relative to the ATG site (17-19), and potential binding sites for activating protein (AP)-1, AP-2, stimulating protein-1 and cAMP response element binding protein have been identified (17), in addition to two sites similar to the consensus sequence for thyroid-specific transcription factor (TTF)1 (18). However, the most relevant finding concerns the absence of the regulatory elements necessary to obtain cell-type specific transcription in a region located proximal to the transcription start site. Differently from that observed in promoters of other genes encoding thyroid-specific proteins, such as thyroglobulin, TPO and TSH receptor, elements within $2 \mathrm{~kb}$ in the $5^{\prime}$-flanking region of recombinant NIS are not sufficient to confer thyroid-selective transcription. However, a less stringent thyroid-specific control of NIS gene expression may be expected, considering that iodide transport also occurs in other tissues (see below). Recently, Ohno et al. (20) reported the presence of an enhancer that is located between nucleotides 2264 and 2495 in the $5^{\prime}$-flanking region of the rat NIS gene. It stimulates transcription in a thyroidspecific and cAMP-dependent manner, in the presence of the transcription factor, PAX-8.

\section{NIS protein expression in thyroid tissue}

The production of specific antibodies against the NIS has facilitated the study of expression of the symporter protein. Despite of the presence of high levels of human (h) NIS mRNA, normal thyroid glands exhibit heterogeneous expression of NIS protein. Immunohistochemical studies showed that only a minority (approximately 30\%) of follicular cells express detectable

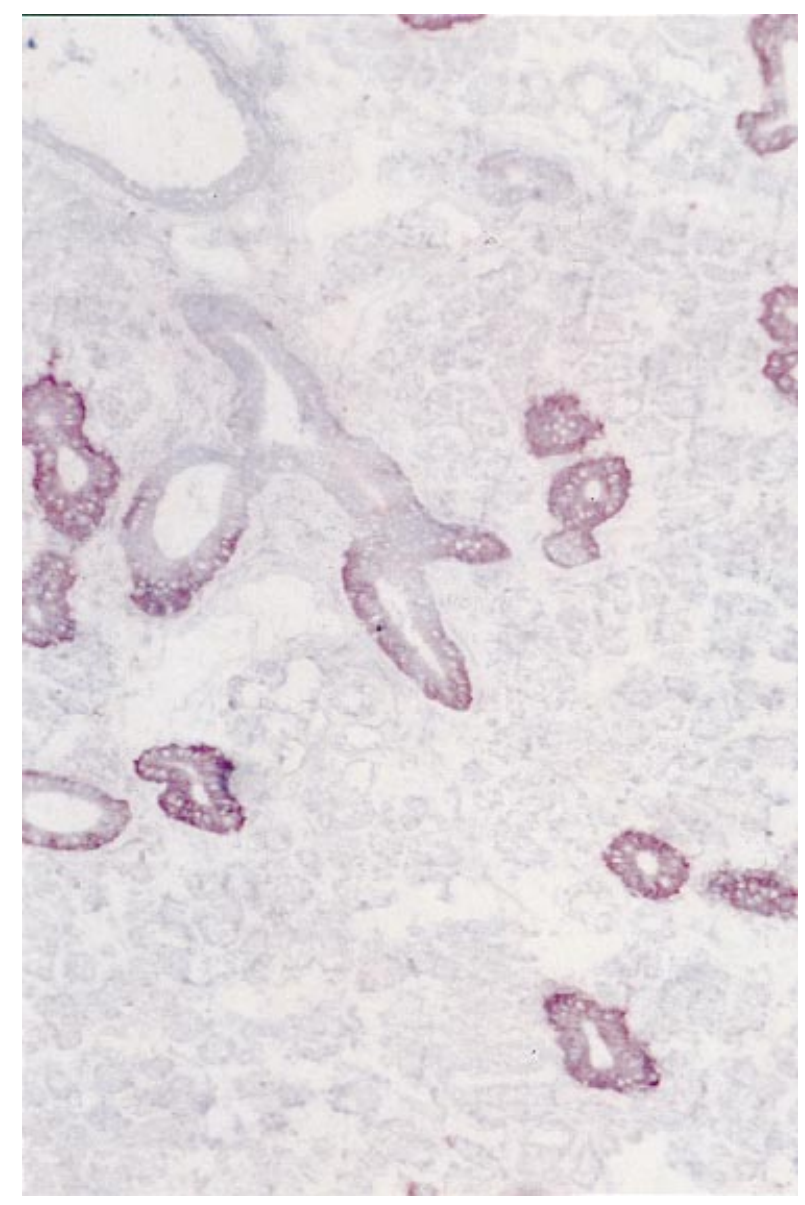

Figure 2 Expression and localization of NIS protein in normal human thyroid tissue (original magnification, $\times 200$ ). Only some follicular cells are stained.

amounts of hNIS protein $(21,22)$ (Fig. 2). Differently, in Graves' disease thyroid glands and toxic adenomas staining of hNIS protein was stronger and was detected in the majority of thyrocytes, corresponding to the high levels of NIS mRNA detected in these tissues $(7,15)$. As expected, cell polarization has been observed, with immunostaining of the NIS protein limited to the basolateral membrane of the thyrocytes (Fig. 3).

In immunoblot experiments, the human NIS protein is detected as a single band of approximately $70-80 \mathrm{kDa}$ $(8,23$, and our unpublished observations), indicating that glysosylation accounts for $\sim 15 \mathrm{kDa}$, along with the $\sim 65 \mathrm{kDa}$ polypeptide backbone, as deduced from its primary structure.

\section{NIS expression in extrathyroidal tissues}

NIS mRNA was also detected in non-thyroid tissues able to concentrate radioiodine (Table 3), including salivary glands, stomach, thymus and breast. Lower levels of expression were detected in prostate, ovary, 
Figure 3 Basolateral localization of the NIS protein in follicular cells from

Graves thyroid tissue (original magnification, $\times 1000)$. Note that all follicular cells are stained, and that staining is more intense in the basal part.

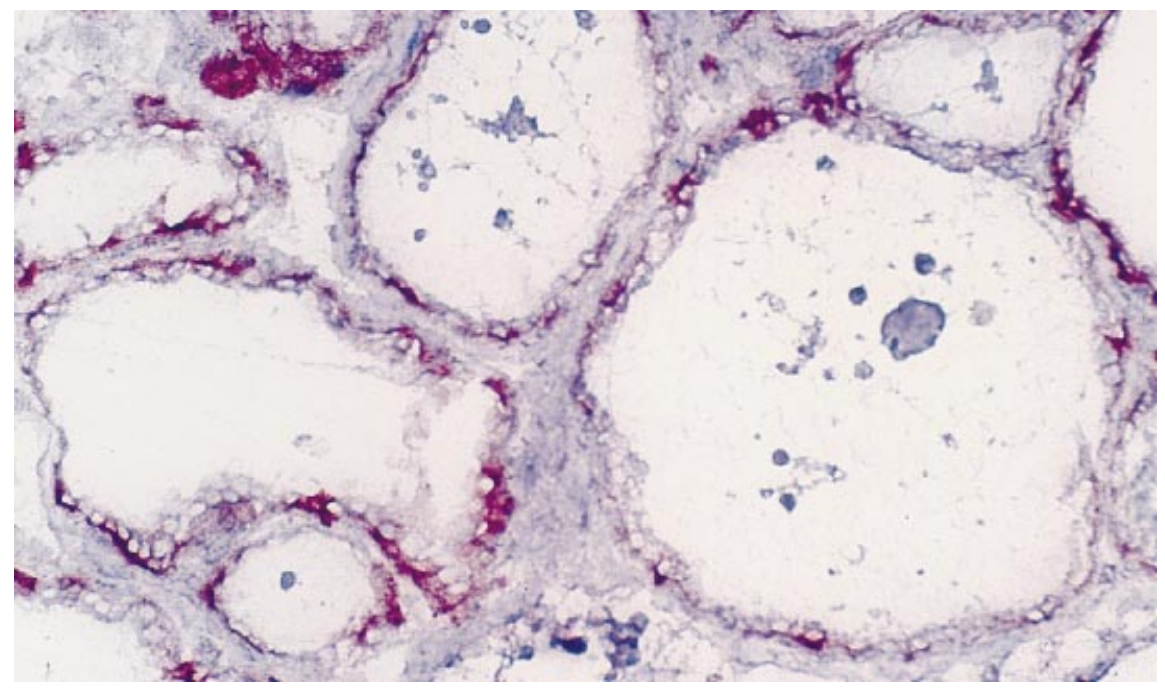

adrenal gland, lung and heart. By contrast, no expression of NIS gene was detected in colon, normal orbital fibroblasts and nasopharyngeal mucosa $(7,24,25)$.

Salivary glands do express hNIS protein, as shown by immunohistochemical studies using a specific antihNIS antibody $(21,26)$. Immunostaining of the NIS protein occurs only in the ductal cells, where it is diffusely expressed within cells, and not in the acinar cells (Fig. 4). In the human stomach, expression of NIS was restricted to parietal cells. Recently, characterization of rat gastric NIS by Western blot analysis showed the presence of a small amount of immature gastric NIS, with different molecular weights compared with the thyroid protein (27). This suggests the existence of tissue-specific post-translational mechanisms in the functional regulation of NIS expression.

\section{Biochemical properties of thyroid cancer tissues}

\section{Alteration of iodine metabolism in cancer tissue}

Although papillary and follicular thyroid carcinomas retain the majority of biological properties of normal

Table 3 NIS transcript and protein expression in human tissues.

\begin{tabular}{lll}
\hline NIS mRNA* & +++ & $\begin{array}{l}\text { Thyroid, salivary gland, parotid gland, } \\
\text { submandibular gland }\end{array}$ \\
& + & $\begin{array}{l}\text { Pituitary gland, pancreas, mammary } \\
\text { gland, gastric mucosa, prostate, } \\
\text { testis, ovary, adrenal gland, thymus, } \\
\text { lung } \\
\text { Orbital fibroblasts, colon, } \\
\text { nasopharyngeal mucosa }\end{array}$ \\
& - & Thyroid, salivary gland
\end{tabular}

* Detected by RT-PCR and Southern hybridization (24).

** Detected by immunohistochemistry $(21,22)$.

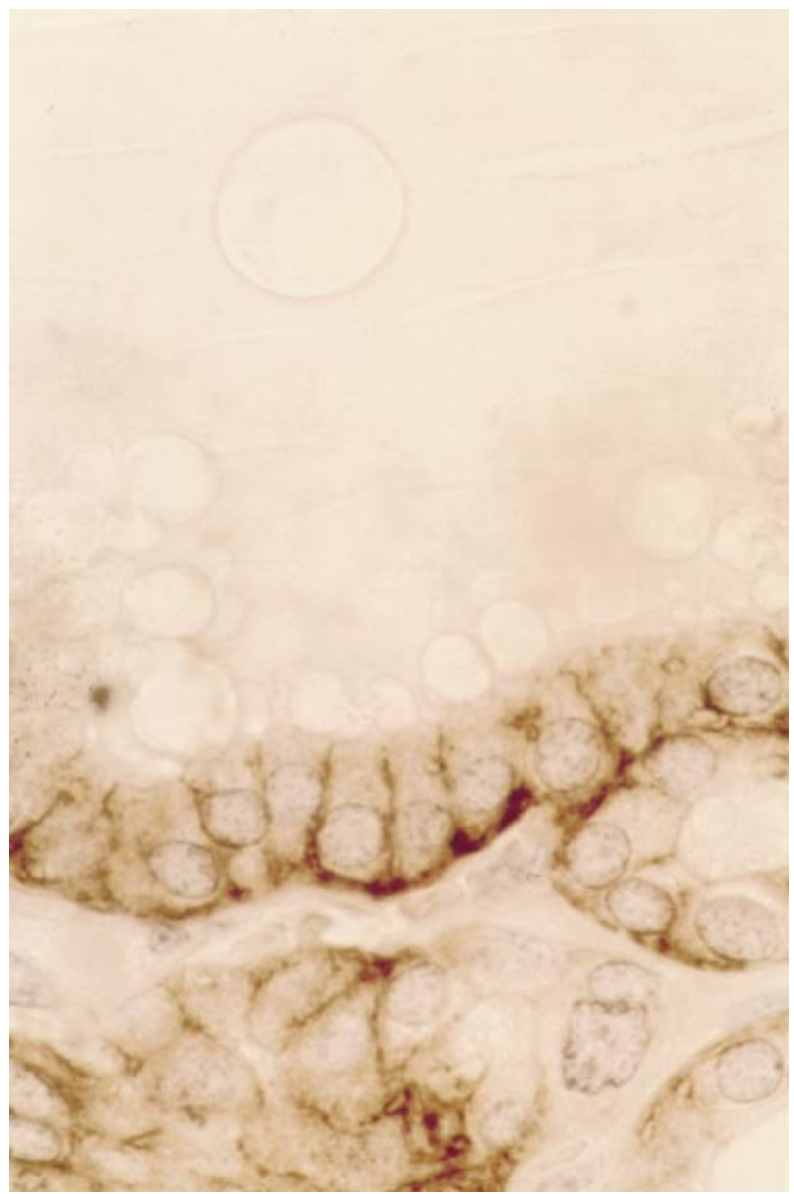

Figure 4 Expression and localisation of NIS in the submaxillary gland (original magnification, $\times 200$ ). Only ductal cells are stained, with diffuse staining within cells. 
thyroid cells, a variety of biochemical defects has been demonstrated (28-30). Indeed, impaired intrathyroidal iodine metabolism represents one of the most peculiar abnormalities present in thyroid neoplastic tissue. The biological activity of peroxidase, although normal in benign cold adenomas, was decreased or absent in thyroid carcinomas, resulting in a low iodine organification. As a consequence, in thyroid cancer tissues, a low intrathyroidal iodine concentration, a low degree of iodination of thyroglobulin and a low rate of thyroid hormones synthesis were observed. The altered iodine intrathyroidal metabolism may confer on tumor cells a proliferative advantage as a result of the loss of the iodine autoregulating process (31).

How and to what extent do the abnormalities of iodine affect the management of patients with thyroid cancer? The derangement of thyroid iodine metabolism accounts for the appearance of adenomas and of the majority of malignant thyroid tumors as hypofunctioning ('cold' nodules) on scintiscan, indicating an impaired radioiodine trapping ability in vivo. Moreover, in vivo studies in patients with metastases have shown that uptake of radioiodine is always less in neoplastic tissue than in its normal counterpart. In fact, tissue uptake of iodine is about $1 \% / \mathrm{g}$ of the administered activity in normal thyroid tissues, whereas it ranges from $0.1 \%$ to $0.001 \%$, or even less in neoplastic tissues. Furthermore, the effective half-life of iodine in neoplastic tissues is, on average, equal to 3-5 days, but sometimes much shorter, whereas it ranges from 6 to 8 days in normal thyroid tissues. This short half-life may be due to abnormalities in the organification process that are, at least in part, related to a defect in the peroxidase system. Increasing the effective half-life of iodine-131 in the thyroid cells by the use of lithium salts significantly increases the dose of radiation to the neoplastic tissue (32). Uptake of iodine131 can be heterogeneous among foci in which uptake occurs, but also in a given focus; this is related to the speckled distribution of radioiodine, which is different from one neoplastic thyroid cell to another, as shown by autoradiographic studies, and is in accordance with the heterogeneous expression of the NIS protein, as shown by immunohistochemistry (see above).

\section{Iodine and thyroid cancer}

\section{Iodide transport and NIS expression in oncogene-transformed thyroid cells}

Proto-oncogene activation, over-expression, or both, have a role in thyroid tumorigenesis and determine a loss of differentiation of thyroid function $(33,34)$.

PC Cl 3 and FRTL-5 are differentiated rat thyroid cells that possess specific markers of thyroid function - namely, thyroglobulin synthesis and secretion, the ability to trap iodide and TSH-dependent growth $(35,36)$. Moreover, the oncogene-transformed cell lines display different degrees of malignancy and differentiation (10). They exhibit a TSH-independent growth, even if some clones require thyrotropin hormone for optimal proliferation when cultured in conditions of low serum concentration. However, all transformed thyroid cells, exibiting either a high or a low degree of malignancy (10; D Russo and S Filetti, unpublished data), display a loss of iodide uptake function. Moreover, whereas all thyroidspecific differentiation markers are lost in highly malignant rat thyroid cell lines (that is, they are transformed by KiMSV, Kirsten murine sarcoma virus), the de-differentiation process appears to be restricted to the loss of iodide uptake in transformed thyroid cells of low malignancy; this suggests that, in vitro, the loss of ability to concentrate iodide is an early effect of oncogenic rat thyroid cell transformation.

Likewise, the phenotype of transformed thyroid cells may make it possible to define, at the molecular level, the mechanisms whereby oncogene-transformed rat thyroid cells lose the ability to trap iodide. The possibility exists that activation of a specific oncogenic pathway may alter the iodide-trapping ability of transformed cells, through an alteration in NIS gene expression. In this regard, we found that some oncogene-transformed cell lines showed very low or absent amounts of NIS transcript compared with normal, non-transformed thyroid cells (10). Oncogenic transformation determines also the loss of other thyroid-specific transcripts thyroglobulin and thyroperoxidase in Ras transformed cells - suggesting that the transcription factors controlling their expression are either not present or inactive (37). Indeed, in K-Ras-transformed cells, both PAX-8 and TTF-1 mRNA are undetectable (38), and in RET/PTC1-transformed cells, PAX-8 is expressed at reduced levels and TTF-1 is inactive (39). PAX-8 expression is lost also in oncogenic transformed cells mediated by p53 and Polyomavirus middle T antigen (37, 39); TTF-2 DNA binding activity is lost in transformed cells by the polyomavirus middle $\mathrm{T}$ antigen $(38,41)$. Other oncogene-transformed cell lines (PC v-erbA, PC HaMSV, PC v-raf, PC E1A) showed reduced NIS mRNA levels when compared with non-transformed cells. These studies suggest the presence of a transcriptional or post-transcriptional event, or both, responsible for the complete loss of iodide uptake function (10).

Figure 5 summarizes the possible targets of alterations in the tumorigenic process that are responsible for the loss of iodide uptake in thyrocytes.

\section{NIS expression and impaired iodine metabolism in thyroid cancer cells}

The recent cloning of the hNIS has provided the possibility to examine, at the molecular level, the mechanism through which thyroid iodide trapping is hampered in human thyroid cancer cells. Using RT-PCR, Smanik PA et al. (25) found NIS expression to variable extents in papillary thyroid carcinomas. However, NIS mRNA was not detected in several thyroid cancer cell lines 


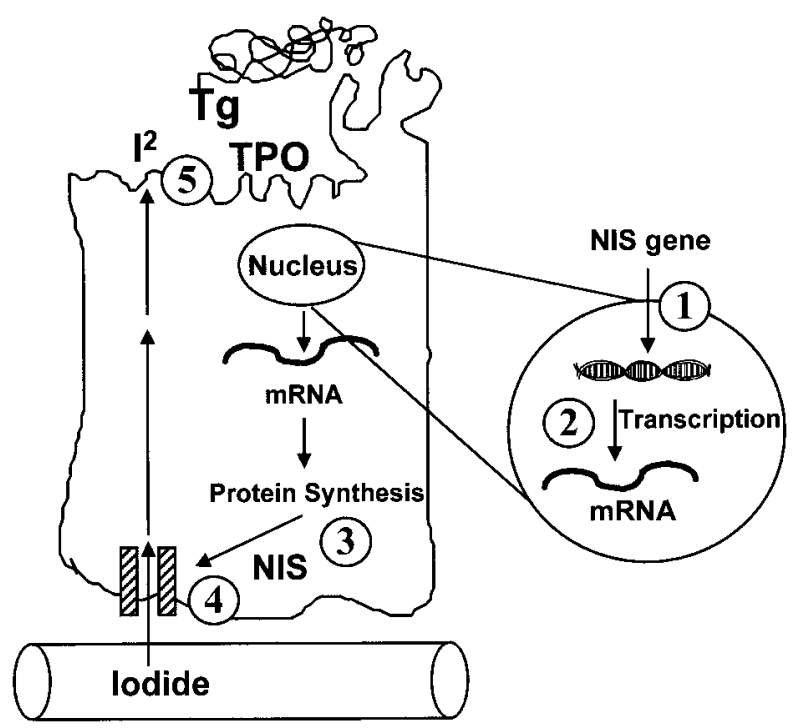

Figure 5 The possible targets of the alterations occurring in the tumorigenic process responsible for the loss of iodide uptake in thyrocytes. 1, Alterations in NIS structural gene; 2, alterations in regulation of NIS transcript expression; 3 , alterations in NIS protein synthesis; 4 , alterations in NIS transport to the plasma membrane; 5 , alterations in iodide organification.

that have lost the ability to concentrate iodide (2). By using non-quantitative RT-PCR in a series of 24 differentiated carcinomas, we found a loss of expression of the iodide symporter gene in six primary thyroid tumors (42); in contrast, all neoplastic tissues studied expressed the $\mathrm{Tg}$ (thyroglobulin) gene. The absence of NIS mRNA transcript, however, was not restricted to the malignant phenotype, being found also in one of 11 'cold' benign follicular adenomas. To identify more precisely the whole array of defects in thyroid-specific gene expression in thyroid tumors, quantitative methods of analysis were applied, based on the fluorescent TaqMan methodology and real-time measurement of fluorescence. This method, by providing accurate and reproducible quantitation of gene copies, enabled examination of the expression of the four functional parameterencoding genes, including NIS, thyroid peroxidase, thyroglobulin and thyrotropin receptor, in a large number of well-characterized microdissected tissues. Whereas in cold benign adenomas the expression of Tg, TSH-R and TPO genes was similar to that observed in normal thyroid tissue, NIS mRNA levels were decreased (2- to 700-fold lower) in the majority of samples studied. In neoplastic thyroid tissues, more extended alterations were detected: NIS mRNA expression, although normal in three samples, was 10 - to 1200-fold lower than in normal tissues (median 100-fold) in another 38 samples; TPO mRNA expression was reduced by 5- to 500-fold and thyroglobulin mRNA by 2- to 300-fold. Interestingly, the expression of TSH-R transcripts was normal in most tumors (V Lazar et al., unpublished observations). Furthermore, later tumor stages (stage $>1$ as opposed to stage 1) were associated with lower levels of expression of NIS $(P=0.03)$ and TPO $(P<0.01)$, but not with the expression of thyroglobulin or TSH-R. Taken together, these data indicate an extreme, peculiar and specific alteration of NIS gene expression in thyroid tumors. Having already been detected in cold follicular adenomas, the low expression of NIS may represent an early abnormality in the thyroid cell transformation pathway, and not be a consequence of cancer progression. Conversely, $\mathrm{Tg}$ gene expression appears to be well conserved in cancer cells, being absent only in undifferentiated cancer tissue (unpublished observations). More interestingly, in human thyroid tumorigenesis, thyroid-specific genes generally display a specific pattern in their alteration (NIS $>$ TPO $>\mathrm{Tg}>\mathrm{TSH}-\mathrm{R}$ ), and this behavior is similar to that observed in vitro in oncogene-transformed rat thyroid cells (see above). Immunohistochemistry using anti-NIS antibodies confirmed the much lower expression of the NIS protein in thyroid cancer tissues, and also demonstrated that its expression was heterogeneous, being detected in only a few malignant papillary or follicular thyroid cells (Fig. 6). In these studies, the serum TSH concentration was in the normal range in all patients at surgery and the amounts of NIS mRNAs obtained, therefore, represent the basal and unstimulated concentrations (22).

These data suggest, in accordance with clinical data, that an intensive TSH stimulation should be performed in patients with thyroid cancer, before any administration of iodine-131, in order to increase NIS expression and thus the ability of thyroid cancer tissue to take up the iodine-131 $(43,44)$. Obviously, the complete/partial reversibility of the uptake function requires the structural integrity of the NIS gene and NIS protein - an issue confirmed by the absence of point mutations or other genetic alterations in a series of thyroid carcinomas screened for genetic abnormalities (M Derwahl, personal communication). All the published studies involved primary cancers only, and thus the possibility exists that their metastases may display a different pattern of expression of thyroid-specific proteins. Although systematic studies on this issue are not yet available, lymph-node metastases arising from differentiated thyroid carcinoma retain, as primary carcinomas, some features of epithelial thyroid cells and transcribe both $\mathrm{Tg}$ and TSH-R genes (45). In contrast, about one-third of thyroid cancer metastatic tissues, although showing $\mathrm{Tg}$ and $\mathrm{TSH}-\mathrm{R}$ transcripts, did not express the NIS gene (F Arturi, D Russo, S Filetti, unpublished observations). Another issue is whether a discrepancy in NIS expression may exist between metastases and primary cancer. In this regard, dot blot analysis demonstrated that, although NIS mRNA expression was maintained in thyroid tumor lymphnode metastases, a lower NIS expression was detected in metastatic tissue, in comparison with the respective 

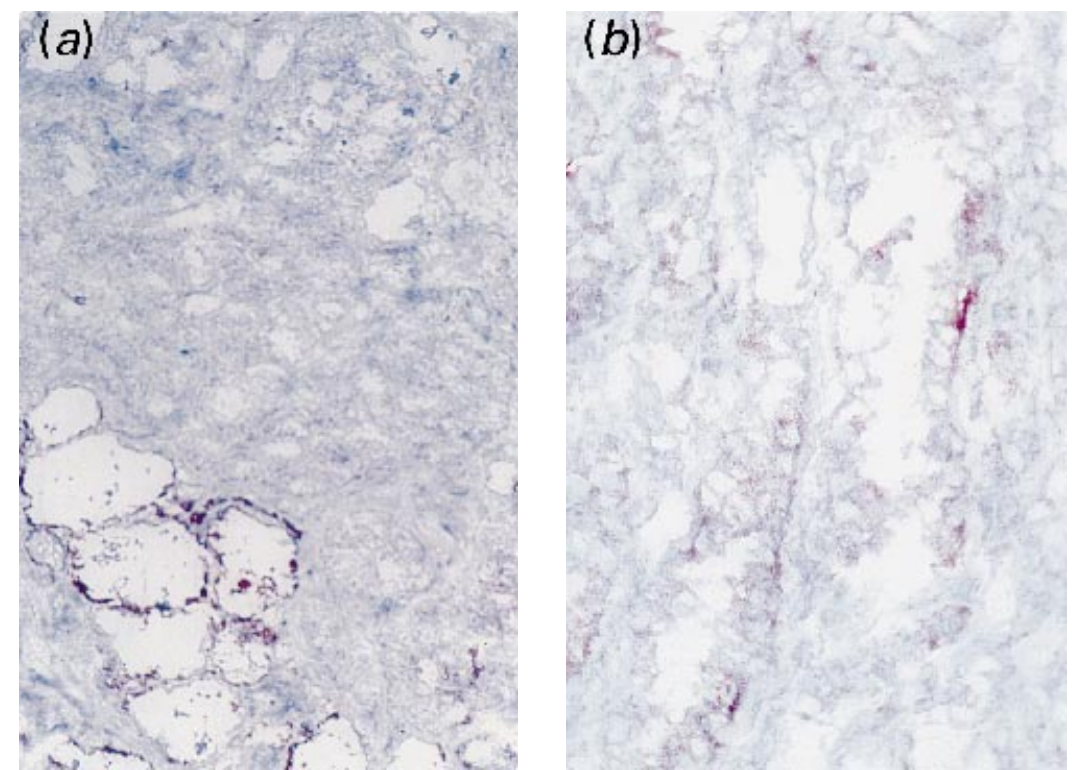

Figure 6 NIS expression in papillary thyroid carcinoma. (a) NIS expression is lower than in normal thyroid tissue (magnification, $\times 200$ ); (b) NIS expression is observed in only some papillary cells (original magnification, $\times 400$ ). primary cancer tissue (Fig. 7). The possibility exists, therefore, that a de-differentiation process may occur in metastases; however, additional studies on this issue are necessary with respect to the clinical application of such a finding. Moreover, in the absence of specific NIS mRNA in the primary tumor, there was no detectable expression of the NIS gene in corresponding lymph-node metastases (Table 4). However, the only data available at present are from tissues collected in the absence of TSH stimulation.

At the present time, the low expression of NIS and of peroxidase genes in thyroid cancer tissues is largely unexplained, although promoter-specific protein:protein or protein:DNA interactions are likely to be involved. Studies of transcription factors and of abnormal methylation of genes are, indeed, being performed.

\section{Radioiodine in the follow-up and treatment of differentiated thyroid carcinoma}

\section{Radioiodine in the follow-up}

Iodine uptake by thyroid cancer cells and blood levels of thyroglobulin are the two cornerstones in the follow-up of patients with thyroid cancer. Indeed, whereas serum thyroglobulin is detectable in most patients with persistent or recurrent disease, radioiodine uptake is found only in about two-thirds of patients with metastatic disease. Detectable production of thyroid hormones is, however, infrequent, unless genetic alterations, such as activating mutations in the TSH receptor, may determine the rare association of thyroid carcinoma and thyrotoxicosis (46-49). These clinical findings are in agreement with the molecular analysis (see above). However, differentiation of normal and of neoplastic thyroid cells depends on TSH stimulation. In fact, iodine uptake is absent during thyroid hormone-suppressive treatments; after withdrawal of thyroid hormone treatment, a close relationship has been observed between the degree of TSH stimulation and the increase of radioiodine uptake in metastases (50). Similarly, serum concentrations of thyroglobulin increase after withdrawal of thyroid hormone treatment in almost all patients with persistent or recurrent disease, even in the absence of radioiodine uptake in the metastases (51). This clearly shows that all these tumor tissues can respond to TSH stimulation, demonstrating the presence of functional TSH receptors in their plasma cell membrane. Indeed, the presence of the TSH-R gene has been exploited also as marker for the early identification of lymph-node metastases from differentiated thyroid carcinoma (45). As thyroglobulin is produced only by thyroid follicular cells, a detectable serum concentration of thyroglobulin after total thyroid ablation indicates persistent or recurrent disease. In fact, during thyroid hormonesuppressive treatment, the majority (about 98\%) of patients with differentiated thyroid carcinoma considered to be in complete remission exhibit an undetectable serum thyroglobulin concentration, whereas high levels were found in the majority of patients with large metastases. However, a serum thyroglobulin concentration was undetectable during L-thyroxine-suppressive treatment in about $20 \%$ of patients with isolated neck lymph-node metastases and in about $5 \%$ of patients with small lung metastases, not observable on standard chest radiographs. After withdrawal of thyroid hormone treatment, the serum concentration of thyroglobulin remained undetectable in most patients in complete remission and increased to a high level in most patients with disease. Therefore, increased TSH concentrations obtained after 

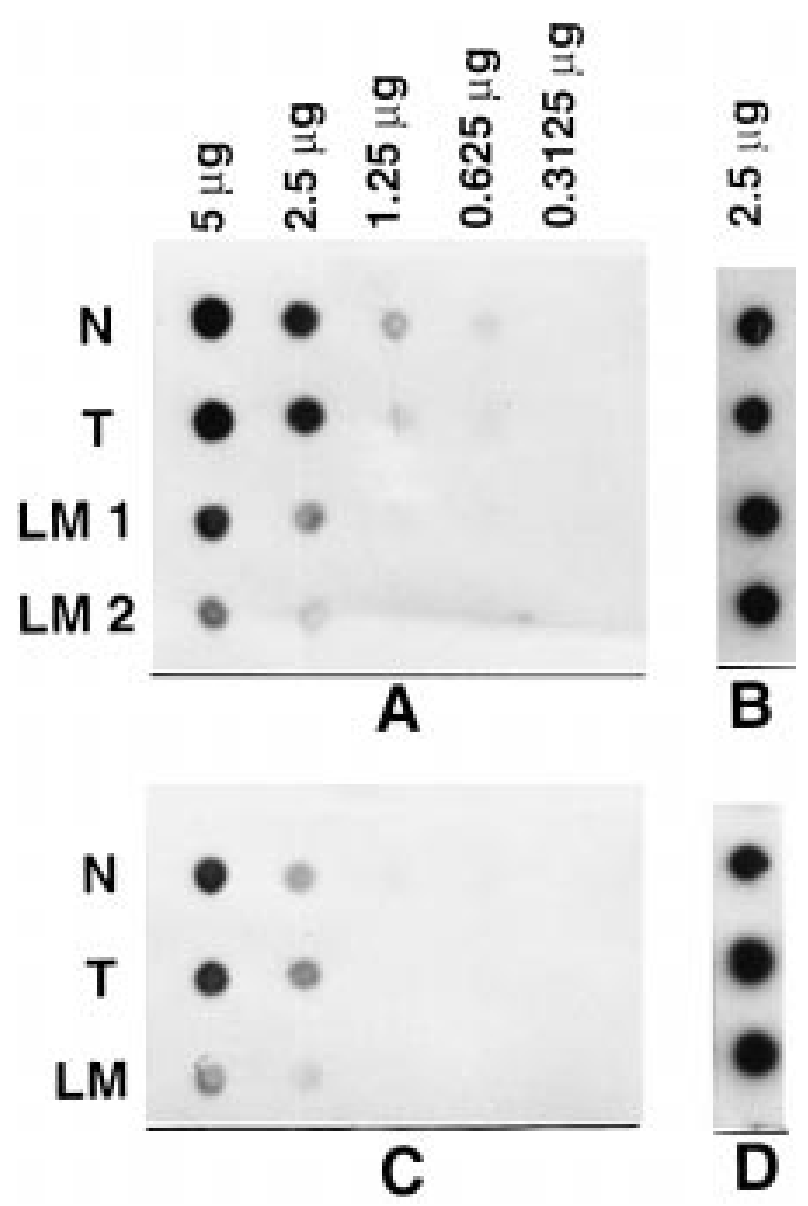

Figure 7 Dot blot hybridization of normal $(\mathrm{N})$, tumoral $(\mathrm{T})$, and metastatic (LM) tissue RNA of two patients with thyroid papillary carcinoma. In panels A and C, total RNA was hybridized with labeled iodide carrier CDNA (EcoRI-HindIII, 1-2046 fragment of rat NIS gene). In panels B and D, total RNA was hybridized with labeled murine actin probe to ascertain equal RNA loading (from Arturi F, Russo D, Schlumberger M, DuVillard JA, Caillou B, Vigneri P, Wicker R, Chiefari E, Suarez HG \& Filetti S. lodide symporter gene expression in human thyroid tumors. Journal of Clinical Endocrinology and Metabolism 199883 2493-2496. (c) The Endocrine Society, with permission).

withdrawal of thyroid hormone treatment increase the sensitivity of serum thyroglobulin determination for the detection of neoplastic disease $(44,51)$.

The localization of neoplastic tissue relies firstly on iodine-131 total body scanning ( ${ }^{131}$ I-TBS) (Fig. 8). The results of ${ }^{131}$ I-TBS depend on the ability of thyroid cancer tissue to take up iodine-131 in the absence of iodine contamination and in the presence of high serum TSH concentrations (e.g. >25-30 mU/l), which are achieved by withdrawing thyroxine for 4-6 weeks. Intramuscular injection of recombinant human (rh) TSH is a promising alternative, because thyroxine does not need to be discontinued and the side effects are minimal. It provides a short but intense stimulation. The results of ${ }^{131}$ I-TBS and of serum thyroglobulin determination performed after the administration of rhTSH and after withdrawal of thyroid hormone treatment are similar in most patients (52).

Iodine uptake in neoplastic tissues is greater and more frequent in younger patients, in those with papillary or well-differentiated thyroid carcinoma and in those with small metastases (53). This suggests an accumulation of metabolic defects with both age and tumor progression. Total-body scanning may also show physiological concentration of iodine-131 in salivary glands, in the stomach, in breast, in the liver (attributable to iodoproteins) and accumulation of iodine-131 in the colon (Fig. 9).

As already mentioned, fractional uptake is often low in thyroid cancer tissue and scanning with a diagnostic dose may be negative. This problem can be overcome by administering a high dose of iodine-131. In fact, assuming equivalent fractional uptake after the administration of a diagnostic or a therapeutic dose of iodine-131, an uptake too low to be detected with 2$5 \mathrm{mCi}$ may be detectable after the administration of $100 \mathrm{mCi}$. This is the rationale for administering $100 \mathrm{mCi}$ iodine-131 to patients with increased serum thyroglobulin concentrations, even in the absence of any other evidence of disease, including a negative diagnostic ${ }^{131}$ I-TBS. When this is done, total-body scanning should be performed 4-7 days later. This strategy enabled the discovery of yet unknown foci of uptake in $60-80 \%$ of those patients treated in this way (44).

In the absence of uptake of iodine-131, computed tomography or magnetic resonance imaging of the neck and lungs, and bone scintigraphy may be useful. Scintigraphy with a less specific tracer has been advocated for the follow-up of patients with thyroid cancer. Such tracers include thallium, metaiodobenzyliodothyrosine (MIBI), tetrofosmin and somatostatin analogs $(54,55)$. They can be used while the patient is receiving thyroxine treatment. In some reports, the sensitivity of these techniques appeared to be high, but they cannot replace ${ }^{131}$ I-TBS in patients with suspected disease, as they do not avoid the use of ${ }^{131}$ I-TBS; therefore, they should be performed only in patients with a negative ${ }^{131}$ I-TBS. Positron emission tomography (PET) using (F18) fluorodeoxyglucose (FDG) is more promising. Enhanced glucose metabolism is a non-specific feature of tumor cells. It can be performed while the patient is receiving thyroxine treatment. However, FDG uptake was found to be greater when thyroxine was withdrawn (56). FDG uptake was detected more frequently in patients with poorly differentiated thyroid carcinoma, in whom no detectable iodine-131 uptake could be demonstrated. It was detected in neck lymph-node metastases, and even in nodes of less than $1 \mathrm{~cm}$ in diameter $(57,58)$. Although highly useful in specific contexts, FDG PET scan cannot supersede ${ }^{131}$ I-TBS, but can and should be performed in patients with a high likelihood of persistent or 
Table 4 Clinical features and $T g, T P O$ and NIS gene expression in a series of differentiated thyroid carcinomas with lymph-node metastases.

\begin{tabular}{|c|c|c|c|c|c|c|c|}
\hline \multirow[b]{2}{*}{ Histotype } & \multirow[b]{2}{*}{ Sex } & \multirow[b]{2}{*}{ Age $(y r)$} & \multirow[b]{2}{*}{ Metastases } & \multirow{2}{*}{$\begin{array}{l}\text { Uptake of } \\
\text { iodine-131 }\end{array}$} & \multicolumn{2}{|c|}{ Thyroglobulin (ng/ml) } & \multirow[b]{2}{*}{ Tg/TPO/NIS } \\
\hline & & & & & $\mathrm{On} \mathrm{T}_{4}$ & Off $\mathrm{T}_{4}$ & \\
\hline Papillary & $\mathrm{F}$ & 23 & + & + & 2.5 & 24 & $+1+1+$ \\
\hline Papillary & $\mathrm{F}$ & 35 & + & + & 9 & 54 & $+1+1+$ \\
\hline Follicular & $\mathrm{F}$ & 55 & + & + & 10 & 38 & $+1+1+$ \\
\hline Follicular & $M$ & 28 & + & + & 17 & 135 & $+1+1+$ \\
\hline Papillary & M & 75 & + & - & 41 & 360 & $+1+1-$ \\
\hline Papillary & $\mathrm{M}$ & 22 & + & - & 32 & 205 & $+1+1-$ \\
\hline Papillary & $\mathrm{F}$ & 25 & + & - & 6 & 37 & $+1+1-$ \\
\hline Follicular & $\mathrm{F}$ & 53 & + & - & 31 & 116 & $+1+1-$ \\
\hline Papillary & $\mathrm{F}$ & 28 & + & - & 25 & 330 & $+1+1+$ \\
\hline Papillary & $\mathrm{F}$ & 40 & + & - & 1 & 30 & $+1+1+$ \\
\hline Papillary & $\mathrm{F}$ & 28 & + & - & 4 & 18 & $+1+1+$ \\
\hline Follicular & $M$ & 57 & + & - & 23 & 100 & $+1+1+$ \\
\hline
\end{tabular}

The NIS and mRNA expression data are referred to primary tumors. When absent from the primary tumor, the NIS transcript was not detectable in corresponding lymph-node metastases. $\mathrm{T}_{4}$, thyroxine.

recurrent disease and a negative high-dose ${ }^{131} \mathrm{I}$-TBS. In some patients showing a negative ${ }^{131}$ I-TBS, we demonstrated absent or very low expression of NIS gene in the neoplastic tissue. This defect appeared to be intrinsic, being present already in the primary thyroid tumor, and not acquired in the metastatic tissues through a further de-differentiation during the process of tumor progression. In some of these tumors with no demonstrable uptake of iodine-131, we found an increased expression of the type 1 glucose transporter ( $\mathrm{V}$ Lazar et al., unpublished observations). These findings may have a clinical impact. In these cases, alternative methods with which to detect metastases, such as PET scan, may be performed.

\section{Radioiodine in the treatment of differentiated thyroid cancer}

The outcome of iodine-131 treatment is related to the effective dose of radiation delivered to the thyroid cancer tissues, which in turn depends on the effective half-life and the radioactive concentration, namely, the ratio of total uptake to the mass of thyroid tissue. A radiation dose greater than 80 Gy should be delivered to obtain cure; if radiation doses are less than $35 \mathrm{~Gy}$, there will be little chance for success. This shows how TSH stimulation and the absence of iodine contamination are important (59, $60)$. The treatment dose of radiation is usually 3.7-5.5 GBq $(100-150 \mathrm{mCi})$ in adults, and approximately $37 \mathrm{MBq}(1 \mathrm{mCi}) / \mathrm{kg}$ body weight in young children. Successive treatments with iodine-131 are given to achieve sufficient doses of radiation to thyroid cancer tissues, and until total ablation of residual uptake is attained on post-treatment total-body scanning (44).

Complete responses to iodine-131 treatment have been observed in 33-50\% of patients with distant metastases that take up iodine-131. The overall survival rate at 10 years from the time of detection of metastases ranges from 25 to $40 \%$. A younger age, a well-differentiated histotype, a positive uptake of iodine131 and a small extent of disease have a favorable impact on outcome $(44,53)$. The disappearance of iodine-131 uptake, despite the persistence of tumor masses, may be related to the speckled distribution of iodine-131 in tumor tissues, which may be due to a heterogeneous expression of the NIS gene; in fact, the maximal path of beta-rays of iodine-131 in biological tissues is $2-3 \mathrm{~mm}$.

In conclusion, iodine-131 treatment is beneficial in some patients with iodine-131 uptake, and mainly in those with small tumor foci. This underlines the need to treat patients with metastases at an early stage, and this is made possible by the combined use of measurement of serum thyroglobulin, and of ${ }^{131}$ I-TBS. This also shows that iodine-131 treatment should be considered as a therapeutic adjunct to surgery, in particular in patients with isolated neck lymph-node metastases. In patients with bone metastases, surgery should be performed, when feasible; in case of radiological abnormalities, external irradiation should be combined with iodine-131 treatment. External radiotherapy may, in fact, deliver homogeneous and high doses of radiation to limited fields and therefore efficiently complement iodine-131 treatment. In patients not amenable to these therapeutic modalities, no other forms of treatment proved to be beneficial. This, again underscores the paramount importance of iodine-131 in the treatment of patients with differentiated thyroid carcinoma (53).

\section{Manipulating NIS expression: gene reactivation and gene treatment}

\section{Gene reactivation}

The possibility to achieve expression and functional stimulation of the NIS gene in thyroid tumor cells has 


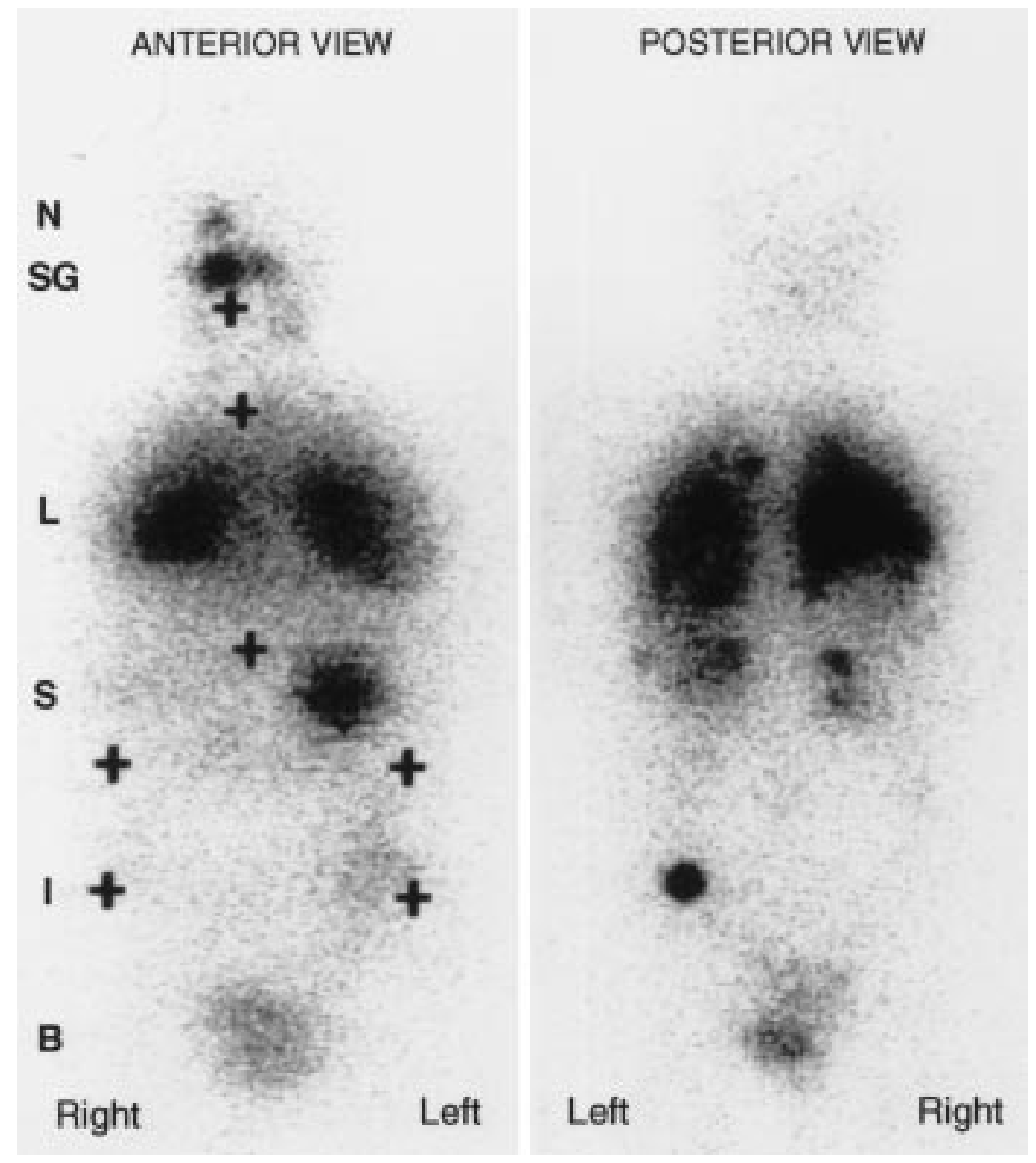

Figure $8{ }^{131}$ I-TBS in a patient with functioning lung metastases (L) and an iliac bone metastasis (I). N, nose; SG, salivary glands; $\mathrm{S}$, stomach; B, bladder.

been exploited for a long time, by using physiological (TSH) or pharmacological agents (retinoic acid, protein kinase activators) $(50,61-63)$. Moreover, they suggest that transcriptional or post-translational events, or both, and not a defective structural NIS gene, occur in the transformation process responsible for the low iodide uptake of the thyrocytes. The goals of several studies, therefore, were to find a means to increase NIS gene expression in order to reverse the loss of iodide uptake observed in some transformed thyroid cells. In fact, expression of NIS mRNA is maintained in some transformed thyroid cell lines, including follicular (64) and anaplastic (19) carcinoma cell lines and oncogene-expressing rat thyroid cell clones (10). However, although an increase in NIS mRNA has been described in vitro in some follicular carcinoma cell lines (FTC-133 and FTC-238) stimulated with retinoic acid, neither an increase in NIS protein nor a reactivation of iodide transport was detected (64). Studies are in progress in our laboratory and by other groups, taking advantage of the outstanding findings on the transcriptional regulation of the NIS gene (20) in order to modulate NIS gene transcription and reverse the loss of iodide uptake in transformed thyroid cells. Elucidation of other post-transcriptional and posttranslational events that occur to achieve the complete function of the thyroid iodide transport system, including the involvement of cofactors or other transporter molecules, such as the recently identified pendrin (65), will be necessary to find the optimal conditions in which to target the thyroid tumoral tissues with radioiodine. 


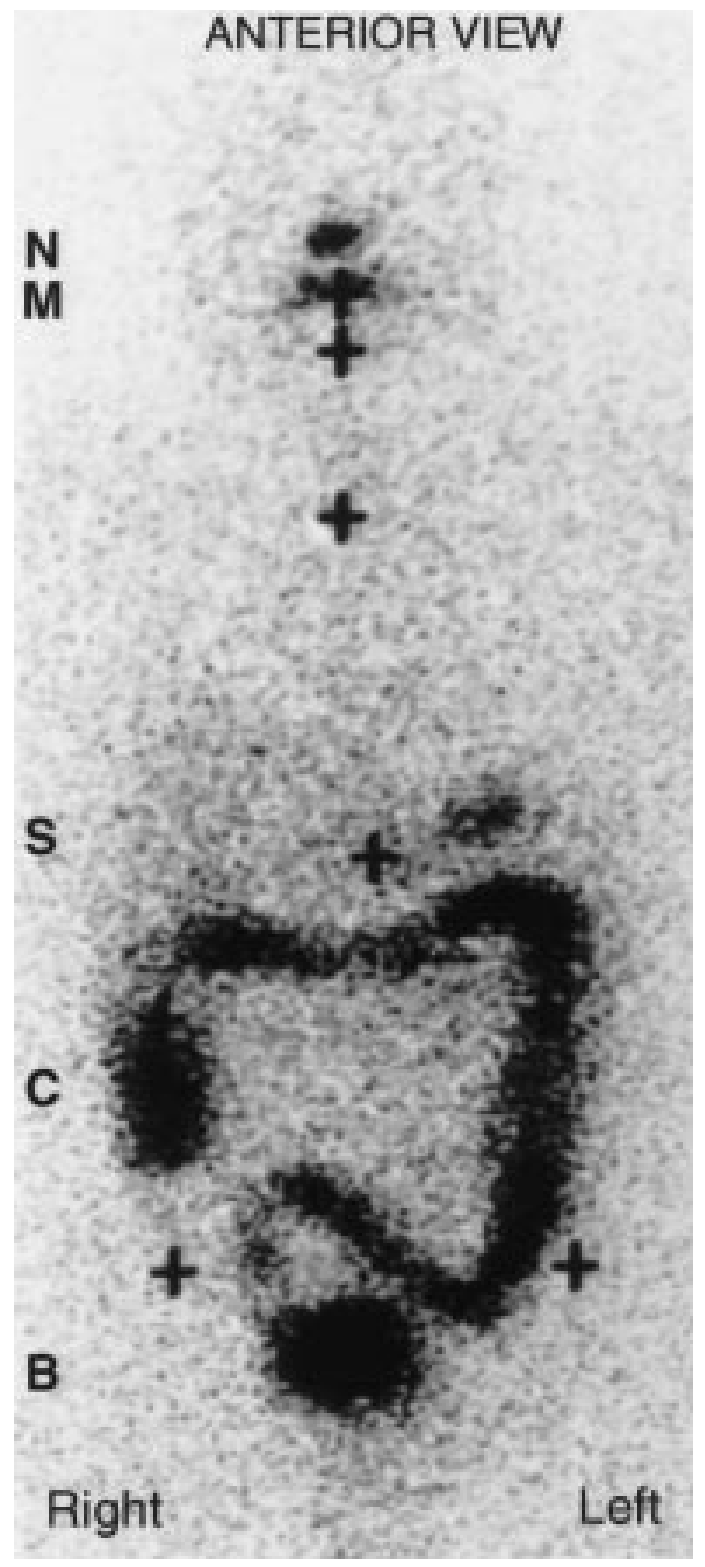

Figure $9^{131}$ I-TBS in a patient with no evidence of disease. Only physiological uptake is seen, in the nose $(\mathrm{N})$, mouth $(\mathrm{M})$ and stomach (S), with accumulation in the colon (C) and in the bladder (B).

\section{Gene therapy}

Combining targeting and expression of the NIS gene together with radioiodine treatment constitutes a powerful new strategy for the treatment of malignant thyroid diseases, in addition to the non-thyroid malignant diseases. The promise of NIS gene therapy lies in the low risk of adverse reactions of gene therapy procedures, in the specific iodide-concentrating effect induced by NIS expression, and in the long-standing experience of radioiodine treatment of patients with thyroid cancer.
Recent papers provided evidence that this approach may prove beneficial in the treatment of radiosensitive cancers. Transfection of rat NIS cDNA into malignantly transformed rat thyroid cells enabled the transfected cells to concentrate iodide, resulting in a 60-fold accumulation of iodine-125 (66). Furthermore, injection of transfected malignant cells into subcutaneous tissues of rats induced solid tumors that were capable of concentrating iodine-125 by 11- to 27-fold. Mandell et al. (67) demonstrated that NIS targeting may be used to deliver $\beta$-emitting radioisotopes to non-thyroid tumors. Retroviral transfer of the NIS gene into human and murine tumor cells, from melanoma, colon, liver or ovarian origin, resulted in an iodide-concentrating ability of infected cells. This approach allowed in vivo radioimaging of human tumor xenografted in mice. Moreover, in vitro experiments indicated that NISinfected tumoral cells can be selectively killed by the induced accumulation of iodine-131.

Although the future of this approach appears promising for in vivo clinical applications, several questions remain unanswered and must be addressed. First, functional NIS targeting requires both the expression of the NIS gene and the adequate posttranslational modification and trafficking of the NIS protein to plasma membrane in target tumor cells, which are known often to lack differentiated functions. Gene expression can be efficiently monitored by engineering appropriate tissue-specific promoters or controlling regulation as described above. Functional expression of the NIS gene in several extrathyroidal tissues appears to be different from that in thyroid tissue. Indeed, characterization of gastric NIS in rat shows that, whereas large amounts of NIS transcripts are expressed, little protein is detected, indicating a rapid degradation of the immature gastric NIS protein (27). In salivary glands, NIS protein is diffusely expressed within cells, suggesting a loss of the polarisation of the symporter. The significance of the variants of the NIS transcripts observed in different tissues, resulting from alternative splicing, remains unknown (25). Assuming that the NIS gene is functionally expressed at a sufficient level, the efficacy of the iodide-concentrating activity has to be demonstrated. Uptake, efflux and saturation kinetics of iodide in tumor cells, particularly those of extrathyroidal origin, are likely to be different from those in normal thyroid cells. Moreover, extra-thyroidal tissues do not efficiently accumulate and organify iodide as does the thyroid tissue, resulting in a short half-life of the iodide. This would suggest that the accumulation of radioactive iodide in tumor cells may not be adequate to achieve sufficient doses of radiation for therapeutic efficacy. Finally, problems also lie in the development of safe and efficient gene-delivery systems (68). Recombinant retroviruses are known to be efficient in in vitro experiments, but result in low infection efficiency in vivo. NIS gene transfer based on adenoviral vectors (which have 
greater transfer efficiencies), liposomes or other vehicle remains to be investigated.

\section{Conclusion}

Available data demonstrate that a decrease, loss, or both, of NIS gene expression may have a central role in the defective concentration of iodine by neoplastic thyroid carcinomas, in both primary or metastatic tissues $(11,25,42,69)$. Although the molecular mechanisms of this loss are unclear, the possibility exists that alterations in the iodide symporter may represent a primary defect; thus, in an originally heterogeneous population, a small number of cancer cells carrying this defect may overgrow over time and determine the appearance of an NIS-negative cell population. Conversely, the clinical utility of administration of iodine-131 in the diagnostic and therapeutic management of patients with differentiated thyroid carcinoma has been well established. In this regard, efforts to elucidate the molecular mechanisms underlying the iodide transport system in thyroid cancer cells will lead to the development of new diagnostic and therapeutic strategies, by allowing a more precisely tailored management of differentiated thyroid cancer.

\section{Acknowledgements}

This work was supported by grants from the Comitè du Val de Marne de la Ligue Nationale Contre le Cancer, the FEGEFLUC, LIPHA Santé, Universitè Paris-Sud (Bonus Qualité Recherche) and the Associazione Italiana per la Ricerca sul Cancro.

F Arturi is a recipient of Dottorato di Ricerca in 'Basi molecolari dell'azione ormonale' at the University of Catania.

\section{References}

1 Dai G, Levy O \& Carrasco N. Cloning and characterization of the thyroid iodide transporter. Nature $1996379458-460$.

2 Smanik PA, Liu Q, Furminger TL, Ryu K-Y, Xing S, Mazzaferri EL \& Jhiang SM. Cloning of the human sodium iodide symporter. Biochemical and Biophysical Research Communications 1996226 339-345.

3 Carrasco N. Iodide transport in the thyroid gland. Biochimica et Biophysica Acta 19931154 65-82.

4 Yoshida A, Sasaki N, Mori A, Taniguchi S, Mitani Y, Ueta Y, Hattori K, Sato R, Hisatome I, Mori T, Shigemasa C \& Kosugi S. Different electrophysiological character of $\mathrm{I}^{-}, \mathrm{ClO}_{4}^{-}$, and $\mathrm{SCN}^{-}$in the transport by $\mathrm{Na}^{+} / \mathrm{I}^{-}$symporter. Biochemical and Biophysical Research Communications 1997231 731-734.

5 Levy O, Dai G, Riedel C, Ginter CS, Paul EM, Lebowitz AN \& Carrasco N. Characterization of the thyroid $\mathrm{Na}^{+} / \mathrm{I}^{-}$symporter with an anti-COOH terminus antibody. Proceedings of the National Academy of Sciences of the USA 199794 5568-5573.

6 Uyttersprot N, Pelgrims N, Carrasco N, Gervy C, Maenhaut C, Dumont JE \& Miot F. Moderate doses of iodide in vivo inhibit cell proliferation and the expression of thyroperoxidase and $\mathrm{Na}^{+} / \mathrm{I}^{-}$ symporter mRNAs in dog thyroid. Molecular and Cellular Endocrinology 1997131 195-203.
7 Ajjan RA, Kamaruddin NA, Crisp M, Watson PF, Ludgate M \& Weetman AP. Regulation and tissue distribution of the human sodium/iodide symporter gene. Clinical Endocrinology 199849 517-523.

8 Saito T, Endo T, Kawaguchi A, Ikeda M, Katoh R, Kawaoi A, Muramatsu A \& Onaya T. Increased expression of the sodium/ iodide symporter in papillary thyroid carcinomas. Journal of Clinical Investigation 1998101 1296-1300.

9 Kogai T, Endo T, Saito T, Miyazaki A, Kawaguchi A \& Onaya T. Regulation by thyroid stimulating hormone of sodium/iodide symporter gene expression and protein levels in FRTL-5 cells. Endocrinology $19971382227-2232$.

10 Trapasso F, Iuliano R, Chiefari E, Arturi F, Stella A, Filetti S, Fusco A \& Russo D. Iodide symporter gene expression in normal and transformed rat thyroid cells. European Journal of Endocrinology 1999140 447-451.

11 Schmutzler C, Winzer R, Meissner-Weigl J \& Kohrle J. Retinoic acid increases sodium/iodide symporter mRNA levels in human thyroid cancer cell lines and suppresses expression of functional symporter in non transformed FRTL-5 rat thyroid cells. Biochemical and Biophysical Research Communications 1997240 832-838.

12 Kawaguchi A, Ikeda M, Endo T, Kogai T, Miyazaki A \& Onaya T. Transforming growth factor- $\beta 1$ suppresses thyrotropin-induced $\mathrm{Na}+/ \mathrm{I}-$ symporter messenger RNA and protein levels in FRTL-5 rat thyroid cells. Thyroid 19977 789-794.

13 Ajjan RA, Watson PF, Findlay C, Metcalfe RA, Crisp M, Ludgate M \& Weetman AP. The sodium/iodide symporter gene and its regulation by cytokines found in autoimmunity. Journal of Endocrinology 1998158 351-358.

14 Isozaki O, Tsushima T, Nozoe Y, Miyakawa M \& Demura H. Oncostatin $\mathrm{M}$ inhibits $\mathrm{Na}^{+} / \mathrm{I}^{-}$- symporter gene expression as well as iodide uptake. Thyroid 19977 (Suppl 1) s-112 (Abstract).

15 Saito T, Endo T, Kawaguchi A, Ikeda M, Nakazato M, Kogai T \& Onaya T. Increased expression of the $\mathrm{Na}^{+} / \mathrm{I}^{-}$symporter in cultured human thyroid cells exposed to thyrotropin and in Graves' thyroid tissue. Journal of Clinical Endocrinology and Metabolism 199782 3331-3336.

16 Kamisky SM, Levy O, Salvador C, Dai G \& Carrasco N. $\mathrm{Na}^{+} / \mathrm{I}^{-}$ symport activity is present in membrane vescicles from TSHdeprived non-I- transporting cultured thyroid cells. Proceedings of the National Academy of Sciences of the USA 199491 3789-3793.

17 Ryu K-Y, Tong Q \& Jhiang SM. Promoter characterization of the human $\mathrm{Na}^{+} / \mathrm{I}^{-}$symporter. Journal of Clinical Endocrinology and Metabolism 199883 3247-3251.

18 Behr M, Schmitt TL, Espinoza CR \& Loos U. Cloning of a functional promoter of the human sodium/iodide symporter. Biochemical Journal $1998331359-363$.

19 Gopalakrishnan M, Venkataraman GM, Yatin M \& Ain KB. Cloning of the human sodium/iodide symporter promoter and characterization in a different human thyroid cell line KAT-50. Thyroid 19988 63-69.

20 Ohno M, Zannini M, Levy O, Carrasco N \& Di Lauro R. The paireddomain transcription factor Pax 8 binds to the upstream enhancer of the rat sodium/iodide symporter gene and participates in both thyroid-specific and cyclic AMP-dependent transcription. Molecular and Cellular Biology 199919 2051-2056.

21 Jhiang SM, Cho J-Y, Ryu K-Y, DeYoung BR, Smanik PA, McGaughy VR, Fischer AH \& Mazzaferri EL. An immunohistochemical study of $\mathrm{Na}^{+} / \mathrm{I}^{-}$symporter in human thyroid tissues and salivary gland tissues. Endocrinology $19981394416-4419$.

22 Caillou B, Troalen F, Baudin E, Talbot M, Filetti S, Schlumberger M \& Bidart J. Immunohistochemical detection of the $\mathrm{Na}^{+} / \mathrm{I}^{-}$ symporter in human thyroid tissues. Journal of Clinical Endocrinology and Metabolism 199883 4102-4106.

23 Kosugi S, Sato Y, Matsuda A, Ohyama Y, Fujeida K, Inomata H, Kameya T, Isozaki O \& Jhiang SM. High prevalence of T354P sodium/iodide symporter gene mutation in Japanese patients with iodide transport defect who have heterogenous clinical pictures. Journal of Clinical Endocrinology and Metabolism 199883 4123-4129. 
24 Spitzweg C, Joba W, Eisenmenger W \& Heufelder AE. Analysis of human iodide symporter gene expression in extrathyroidal tissues and cloning of its complementary deoxyribonucleic acids from salivary gland, mammary gland, and gastric mucosa. Journal of Clinical Endocrinology and Metabolism 1998831746 1751 .

25 Smanik PA, Ryu K-Y, Theil KS, Mazzaferri EL \& Jhiang SM Expression, exon-intron organization, and chromosome mapping of the human sodium iodide symporter. Endocrinology 1997138 3555-3558.

26 Vayre L, Sabourin JC, Caillou B, Ducreux M, Schlumberger M \& Bidart JM. Immunohistochemical analysis of $\mathrm{Na}^{+} / \mathrm{I}^{-}$symporter distribution in human extra-thyroidal tissues. European Journal of Endocrinology $1999141382-386$

27 Kotani T, Ogata Y, Yamamoto I, Aratake I, Kawano J-I, Saganuma $\mathrm{T} \&$ Ohtaki S. Characterization of gastric $\mathrm{Na}^{+} / \mathrm{I}^{-}$ symporter of the rat. Clinical Immunology and Immunopathology $199889271-278$.

28 Thomas-Morvan C, Nataf B. \& Tubiana M. Thyroid proteins and hormones synthesis in human thyroid cancer. Acta Endocrinologica 197476 651-669.

29 Valenta LJ. Thyroid peroxidase, thyroglobulin, cAMP and DNA in human thyroid. Journal of Clinical Endocrinology and Metabolism $197643466-469$.

30 Fragu P \& Nataf BM. Thyroid peroxidase activity in benign and malignant thyroid disorders. Journal of Clinical Endocrinology and Metabolism 197745 1089-1096.

31 Filetti S \& Rapoport B. Autoregulation by iodine of thyroid protein synthesis: influence of iodine on aminoacid transport in cultured thyroid cells. Endocrinology 1984114 1379-1385.

32 Koong SS, Reynolds JC, Movius EG, Keenen AM, Ain KB, Lakshmanan \& Robbins J. Lithium as a potent adjuvant to ${ }^{131}$ therapy of metastatic, well differentiated thyroid carcinoma. Journal of Clinical Endocrinology and Metabolism 199984 912-916.

33 Winford-Thomas D. Molecular genetics of thyroid cancer. Trends in Endocrinology and Metabolism $19934224-232$.

34 Farid NR. Molecular pathogenesis of thyroid cancer: the significance of oncogenes, tumor suppressor genes, and genomic instability. Experimental and Clinical Endocrinology and Diabetes $19961041-12$.

35 Fusco A, Berlingieri MT, Di Fiore PP, Portella G, Grieco M \& Vecchio G. One- and two-step transformations of rat thyroid epithelial cells by retroviral oncogenes. Molecular and Cellular Biology 19877 3365-3370.

36 Santoro M, Melillo RM, Grieco M, Berlingieri MT, Vecchio G \& Fusco A. The TRK and RET tyrosine kinase oncogenes cooperate with ras in the neoplastic transformation of a rat epithelial cell line. Cell Growth and Differentiation 19934 77-84.

37 Avvedimento VE, Musti AM, Ueffing M, Obici S, Gallo A, Sanchez M, DeBrasi D \& Gottesman ME. Reversible inhibition of thyroid-specific trans-acting factor by Ras. Genes Development $1991522-28$.

38 Francis-Lang H, Zannini MS, De Felice M, Berlingieri MT, Fusco A \& Di Lauro R. Multiple mechanisms of interference between transformation and differentiation in thyroid cells. Molecular and Cellular Biology 199212 5793-5800.

39 De Vita G, Zannini M, Cirafici AM, Melillo RM, Di Lauro R, Fusco A \& Santoro M. Expression of the RET/PTC1 oncogene impairs the activity of TTF-1 and Pax-8 thyroid transcription factors. Cell Growth and Differentiation 1998 9 97-103.

40 Battista S, Martelli ML, Fedele M, Chiappetta G, Trapasso F, De Vita G, Battaglia C, Santoro M, Viglietto G, Fagin JA \& Fusco A. A mutated p53 gene alters thyroid cell differentiation. Oncogene $1995112029-2037$.

41 Missero C, Cobellis G, De Felice M \& Di Lauro R. Molecular events involved in differentiation of thyroid follicular cells. Molecular and Cellular Endocrinology 1998140 37-43.

42 Arturi F, Russo D, Schlumberger M, DuVillard JA, Caillou B, Vigneri P, Wicker R, Chiefari E, Suarez HG \& Filetti S. Iodide symporter gene expression in human thyroid tumors. Journal of Clinical Endocrinology and Metabolism 199883 2493-2496.

43 Thomas-Morvan C, Carayon P, Schlumberger M, Vignal A \& Tubiana M. Thyrotrophin stimulation of adenylate cyclase and iodine uptake in human differentiated thyroid cancer. Acta Endocrinologica $198210125-31$.

44 Schlumberger M. Papillary and follicular thyroid carcinoma. New England Journal of Medicine 1998338 297-306.

45 Arturi F, Russo D, Giuffrida D, Ippolito A, Perrotti N, Vigneri R \& Filetti S. Early diagnosis by genetic analysis of differentiated thyroid cancer metastases in small lymph nodes. Journal of Clinical Endocrinology and Metabolism 199782 1638-1641.

46 Russo D, Tumino S, Arturi F, Vigneri P, Grasso G, Filetti S \& Belfiore A. Detection of an activating mutation of the thyrotropin receptor in a case of an autonomously hyperfunctioning thyroid insular carcinoma. Journal of Clinical Endocrinology and Metabolism 199782 735-738.

47 Spambalg D, Sharifi N, Elisei R, Gross JL, Medeiros-Neto G \& Fagin JA. Structural studies of the thyrotropin receptor and Gs $\alpha$ in human thyroid cancer: low prevalence of mutations predicts infrequent involvement in malignant transformation. Journal of Clinical Endocrinology and Metabolism 199681 3898-3901.

48 Russo D, Wong MG, Costante G, Chiefari E, Treseler PA, Arturi F, Filetti S \& Clark $\mathrm{OH}$. A Val 677 activating mutation of the thyrotropin receptor in a Hürthle cell thyroid carcinoma associated with thyrotoxicosis. Thyroid 1999 9 13-17.

49 Russo D, Arturi F, Chiefari E \& Filetti S. Molecular insights into TSH receptor abnormality and thyroid disease. Journal of Endocrinological Investigation 199720 36-47.

50 Schlumberger M, Charbord P, Fragu P, Gardet P, Lumbroso J, Parmentier C \& Tubiene M. Relationship between thyrotropin stimulation and radioiodine uptake in lung metastases of differentiated thyroid carcinoma. Journal of Clinical Endocrinology and Metabolism 198357 148-151.

51 Schlumberger M \& Baudin E. Serum thyroglobulin determination in the follow-up of patients with differentiated thyroid carcinoma. European Journal of Endocrinology 1998138 249-252.

52 Ladenson PW, Braverman LE, Mazzaferri EL, Brucker-Davis F, Cooper DS, Garber JR, Wondisford FE, Davies TF, DeGroot LJ, Daniels GH, Ross DS \& Weintraub BD. Comparison of administration of recombinant human thyrotropin with withdrawal of thyroid hormone for radioactive iodine scanning in patients with thyroid carcinoma. New England Journal of Medicine 1997337 888-896.

53 Schlumberger M, Challeton C, De Vathaire F, Travagli JP, Gardet P, Lumbroso JD, Francese C. Fontaine F, Richard M \& Parmentier C. Radioactive iodine treatment and external radiotherapy for lung and bone metastases from thyroid carcinoma. Journal of Nuclear Medicine 199637 598-605.

54 Lind P, Gallowitch HJ, Langsteger W, Kresnik E, Mikosch P \& Gomez I. The value of Tc $99 \mathrm{~m}$. Tetrofosmin whole body scintigrafy in follow up of differentiated thyroid carcinoma. Journal of Nuclear Medicine 199738 348-352.

55 Baudin E, Schlumberger M, Lumbroso J, Travagli JP, Caillou B \& Parmentier C. Octreotide scintigraphy in patients with differentiated thyroid carcinoma: contribution for patients with negative radioiodine scan. Journal of Clinical Endocrinology and Metabolism 199681 2541-2544.

56 Sisson JC, Ackermann RJ, Meyer MA \& Wahl RL. Uptake of 18-fluoro-2-deoxy-D-glucose by thyroid cancer: implications for diagnosis and therapy. Journal of Clinical Endocrinology and Metabolism 199377 1090-1094.

57 Feine U, Lietzenmayer R, Hanke JP, Held J, Wohrle H \& Muller-Schauenburg W. Fluorine-18-FDG and iodine 131 uptake in thyroid cancer. Journal of Nuclear Medicine 199637 $1468-1472$

58 Grunwald F, Menzel C, Bender H, Palmedo H, Willkomm P, Ruhlmann J, Franckson T \& Biersack HJ. Comparision of 18FDGPET with 131iodine and $99 \mathrm{mTc}$ sestamibi scintigraphy in differentiated thyroid carcinoma. Thyroid $19977327-335$. 
59 Maxon HR, Thomas SR, Hertzberg VS, Kereiakes JG, Chen IW Sperling ML \& Saenger EL. Relation between effective radiation dose and outcome of radioiodide therapy for thyroid cancer. New England Journal of Medicine 1983309 937-941.

60 Maxon HR \& Smith HS. Radioiodine-131 in the diagnosis and treatment of metastatic well differentiated thyroid cancer Endocrinology and Metabolism Clinic of North America 199019 685-718.

61 Goldman JM, Line BR, Aamodt RL \& Robbins J. Influences of triiodothyronine withdrawal time on ${ }^{131}$ I uptake postthyroidectomy for thyroid cancer. Journal of Clinical Endocrinology and Metabolism 198050 734-739.

62 Simon D, Koehrle J, Schmutzler C, Mainz K, Reiners C \& Roeher HD. Redifferentiation therapy of differentiated thyroid carcinoma with retinoic acid: basic and first clinical results. Experimental and Clinical Endocrinology and Diabetes 1996104 13-15.

63 Morris JC, Kim CK, Padilla ML \& Mechanik JI. Conversion of non-iodine-concentrating differentiated thyroid carcinoma metastasis into iodine-concentrating foci after anticancer chemotherapy. Thyroid $1997763-66$.

64 Schmutzler C, Winzer R, Meissner-Weigl J \& Kohrle J. Retinoic acid increases sodium/iodide symporter mRNA levels in human thyroid cancer cell lines and suppresses expression of functional symporter in non transformed FRTL-5 rat thyroid cells. Biochemical and Biophysical Research Communications 1997240 832-838.

65 Scott DA, Wang R, Kreman TM, Sheffield VC \& Karniski P. The Pendred Syndrome gene encodes a chloride-iodide transport protein. Nature Genetics 199921 440-443.

66 Shimura H, Haraguchi K, Miyazaki A, Endo T \& Onaya T. Iodide uptake and experimental ${ }^{131} \mathrm{I}$ therapy in transplanted undifferentiated thyroid cancer cells expressing the $\mathrm{Na}^{+} / \mathrm{I}^{-}$ symporter gene. Endocrinology 1997138 4493-4496.

67 Mandell RB, Mandell LZ \& Link CJ. Radioisotope concentrator gene therapy using the sodium/iodide symporter gene. Cancer Research $199959661-668$.

68 Anderson WF. Human gene therapy. Nature 1998392 25-30.

69 Schmutzler C \& Kohrle J. Implications of the molecular characterization of the sodium-iodide symporter (NIS). Experimental and Clinical Endocrinology and Diabetes 1998106 (Suppl 3) S1-S9.

Received 21 June 1999

Accepted 21 July 1999 